European Journal of Accounting, Auditing and Finance Research

Vol.8, No. 5, pp.66-84, May 2020

Published by ECRTD-UK

Print ISSN: 2053-4086(Print), Online ISSN: 2053-4094(Online)

\title{
FIRMS DEBT STRUCTURE AND SHAREHOLDER RETURNS: MODERATING ROLE OF FOREIGN DIRECTOR OF MULTINATIONAL COMPANIES IN NIGERIA
}

\author{
James George Apochi, FCA (Corresponding Author) \\ Bursary Department, Air Force Institute of Technology, \\ Nigeria Airforce Base, Kaduna, Kaduna, Nigeria \\ +2348036455513 ,
}

Isiaka Olalekan Lasisi

$\mathrm{PhD}$ Accounting and Finance Student, Department of Accounting, Business School, Ahmadu Bello University, Zaria, Nigeria. $+2348037322585$

Tijani Bashir Musa, $\mathrm{PhD}$

Department of Business Administration, Ahmadu Bello University, Zaria $+2348067143514$

\begin{abstract}
Financing decision is one of the important areas in managerial finance to increase shareholders' wealth. Firms can use either debt or capital to finance their business. This study uses two-stage least squares model and examines the impact of foreign directors as moderating variable on the relationship between firm debt structure and shareholders' returns of quoted multinational firms in Nigeria. Secondary data were extracted from the annual reports of six (6) most active quoted multinationals firms on the Nigerian Stock Exchange for the period 2006 to 2018. After running the OLS regression, a robustness test was conducted for validity of statistical inferences. A multiple regression was employed using PCSE regression model and FGLS regression model respectively for model one and two. The study documents in model one that debt to total asset has a positive and significant effect on shareholder returns while debt to equity and debt to turnover have negative and significant effect on shareholders returns though foreign director has no significant impact of shareholder returns. The model two, revealed the moderating role of foreign director, where the debt to equity has a positive and significant effect on shareholder returns while debt to turnover revealed a negative and significant effect on the return to shareholder funds. Though, debt to total asset has no significant effect on shareholders returns. In line with the findings, the study recommended that board of directors of the study firms should ensure that listed multinationals firms in Nigeria should appoint foreigner in their board composition so that the interest of various shareholder's would be fully protected by avoiding unnecessary debt and proper management of the company debt file and sales improve upon their turnover and reduction of unnecessary cost.
\end{abstract}

KEYWORDS: debt structure, shareholder returns, multinational firms, Nigeria

\section{INTRODUCTION}

The outbreak of the Coronavirus pandemic has led to disruptions to the global economy and people's lives, with adverse effects in the debt structure of company, loan to deposit ratio of 
for banks, global oil price, investments, supply chains, capital markets, funding of the 2020 budget among others. These highlighted conditions and others negatively affect Nigeria's macroeconomic stability and resilience to external shock. The implication of the COVID 19 has negatively affect the operational activities and debt services of companies and this may lead to bankruptcy in the long run due to poor performance.

There has been a growing interest worldwide in identifying the factors influencing debt structure decisions of firms. Debt and equity choices are one of the major financial decisions for every companies which may affect its value (Abbasi \& Delghandi, 2016). The primary objective of the firm is to maximize the shareholders wealth by selecting an appropriate mix of the sources of finance for a firm including retained earnings, proceeds from the issue of ordinary shares, preference shares and debt (Afza, Talat., Amer, 2011). Debt is the amount payable within a specified period to the creditors of the company. As debt increases, financial leverage increases. However, financial leverage of a company can determines the value shareholders returns. Therefore, it is important for financial manager to properly manage the company's debt structure in order to allow shareholders earn a better return on their investment.

According to Innocent, Ikechukwu, and Nnagbogu, (2014) the primary motive of a company in using financial leverage is to magnify the shareholders' return under favourable economic conditions. Also, how an organization is financed is of paramount importance to both the managers of the firms and providers of funds (Chinaemerem \& Anthony, 2012). Thus, a wrong combination of capital may negatively affect the performance and survival of the business operation. In Nigeria, the relationship between debt structure and shareholder return is ambiguous. Some firms are not in operations, while some firms are at the bridge of collapse due to high debt incurred.

Past empirical studies have separately examined debt structure of firms in relation to shareholders returns by using two main proxies of debt ratios such as debt to equity and debt to total asset, such as the research work of Abubakar \& Garba, (2019), Fali et al., (2019), Lasisi et al., (2017) Abubakar, (2017), Musah \& Kong, (2019) researched on debt to equity, while Sathyamoorthi et al., (2019), Afolabi et al., (2019) Kariyawasam, (2019), Ahmad and Mohsin, (2016) studied on debt to asset. This research work tend to fill the research gap by including debt to turnover ratio as a measure of additional independent variable. However, the use of debt to turnover ratio is to determine the liquidity position of the company. Furthermore, few studies on moderating role have been conducted in developing countries and Nigeria in particular. No study has yet examined the moderating roles of foreign director on the effect of debt structure on shareholder returns of multinational companies in Nigeria.

This research work therefore makes a daring attempt of finding out the extent of the impact of firm debt structure on shareholder returns. It also attempts to examine how foreign director influences the debt structure of multinationals companies in Nigeria. This study is expected to reveal the predictive power of firm foreign directors in the board composition on debt structure of Nigeria multinational firms. The objective of this study is to examine the effect of firms debt structure on shareholder returns: moderating role of foreign director of multinational companies in Nigeria.

\section{Research Hypotheses}

The research tested the following null hypotheses: 
H01: firm's debt structure does not have significant effect on shareholder returns of multinational companies in Nigeria.

H02: foreign director as moderating role does not have significant impact on firms debt structure and shareholder returns of multinational companies in Nigeria.

\section{LITERATURE REVIEW}

\section{Theoretical and Conceptual Review}

The concept of debt structure and shareholder returns emanated from the agency theory in the work of (Ongore, 2013). Agency theory contributes that leverage firms are better for shareholders as debt level can be used for monitoring the managers. Thus, higher leverage is expected to lower agency costs, reduce inefficiency and thereby lead to improvement in a firm's performance (Chinaemerem \& Anthony, 2012). The studies of Kouse, Bano, Azeem, \& Hassan, (2012) , Jain, Jayaraman, and Kini, (2007) are in support of the agency theory. However, principal-agent theory explains that the principal (the shareholder) desires the agent (the manager) to maximise shareholder returns (Raithatha \& Komera, 2016). Shareholder returns is referring to as the returns or earnings on the equity of a company shareholders over a period.

The concept of debt structure has been widely discussed locally and internationally after the global financial crisis. Debt structure refers to the proportion of debt to equity in the capital structure of a firm. It strives to measure what portion of the total assets is financed by debt funds. Debt structures refer to as leverage. Leverage ratios are used to measure business and financial risks of a firm (Okwoli, 2006). It is measure by long term debt-to-fixed asset ratio (Olumide, Muhammad \& Terzungwe, 2016). According to Osuji \& Odita, (2012) firms use equity and debt to finance their operation with the hope of improving their financial performance. Bhutta, \& Hasan, A. (2013) in their study, state that profitable firms will have less extent of leverage. Leverage is the amount of debt used to finance other capital expenditure that can improve firm financial performance (Pandey, 2005).

Total debt includes short and long-term borrowings from financial institutions, debentures/bonds, differed payment arrangement for buying capital equipment, bank borrowings, public deposit and any other interest-bearing loan (Pandy, 2005). Debt to equity ratio is a tool used to evaluate the corporate financial standing and ability of repayment of its obligations. If the debt to equity ratio increases, the company experiences difficult situation because it is financed by creditors rather than its resources that might be a dangerous trend (Sangmi and Tabassum, 2010).

According to the study conducted by (Kariyawasam, 2019) view debt structure or leverage or the gearing ratio has been calculated as the ratio between total debt to total assets. Further argued that higher gearing will deteriorate the company performance, as lenders and banks related to the organization will perceive the higher leverage as having financial difficulties and as an indication of financial risk. Therefore, a higher leverage ratio would act as a red flag to the organization.

The investors and lenders prefer the low debt to equity because of their interest protection in the corporate decline. Therefore, leverage can be viewed as the financing structure of firms and 
this financing method can either be debt or equity financing and or combination of both debt and equity. This study therefore used both short term debt and long-term debt as a total debt to equity, debt to firm asset and debt to turnover to determine shareholders returns. However, the relationship between firm debt structure and shareholder returns has received considerable attention in the literature.

\section{Empirical Review}

Elshaday et al., (2018) examine the determinants of the financial performance of eight private commercial banks in Ethiopia from 2007 to 2016. The study used correlation and multiple linear regressions of panel data for the analysed using random effect model. E- Views 9 software was used for analysing the data. Results show that Leverage Ratio (LR) has negative and statistically significant effect on banks' financial performance (ROE).

Fali et al., (2019) investigate the effect of leverage on financial performance of Islamic Banking in Nigeria for the period of 2012 to 2017. Ex post research design was adopted. This study concludes that between debt to equity has a positive and insignificant effect on ROE. Furthermore, Lasisi et al., (2017) empirically examined the determinants of business organisation profitability of four (4) listed agricultural companies in Nigeria for the period 2008-2016. The panel data was analysed using multiple regression techniques and the findings of the study reveal that leverage has a negatively and significant influence on profitability (ROE).

Swain \& Das, (2017) examine the impact of capital structure and on financial performance and its determinants of 50 top manufacturing companies. Regression model has been used adopted for the study and concludes that capital structure has a significant and positive impact on profitability (ROE). In addition, Ahmad and Mohsin, (2016) gauge the impact of capital structure (leverage) on the financial performance of 14 companies listed on the KSE in the cement sector for a period of seven years from 2009 - 2015. The results of the study show that leverage measured by Debt to Assets has a statistically significant negative impact on firms' financial performance.

Abubakar \& Garba, (2019) examined the effect of financial leverage on the financial performance of seven companies quoted on the Services Sector in Nigerian during the period 2005- 2016. Fixed Effects Model was used to present the findings of the study and revealed that total-debt equity ratio has a significant negative effect on the financial performance measured by return on equity. The study concludes that decrease in the total-debt equity ratio will improve financial performance. Also, Mule and Hons, (2015) investigated the relationship between financial leverage and the financial performance of listed firm in Kenya over a period 2007 - 2011. The study finds reasonably strong evidence that financial leverage significantly, and negatively, affects the performance. Financial leverage negative and insignificantly affect ROE.

Abubakar, (2017) analysed the effect of financial leverage on the financial performance of eleven (11) quoted industrial goods firms in Nigeria, during the period 2005-2016. The panel data technique was adopted for the study. The major findings indicate that total-debt equity ratio (TDER) has significant negative effect on the financial performance surrogated by the return on equity (ROE). In the same vein, Hussain, Rao, Akram, and Fayyaz, (2015) examined 
the effect of financial leverage on efficiency of 154 textile firms in Pakistan over the period 2006-2011. The regression results indicate that financial leverage has s negative and significant impact on returns on equity.

Musah \& Kong, (2019) examine the relationship between leverage and the financial performance of non-financial firms listed on the Ghana Stock Exchange (GSE) for the period 2008 to 2017. From the result of Pearson Product-Moment Correlation Coefficient output, leverage had an insignificantly positive association with the firms' ROE. More so, Gweyi and Karanja, (2014) investigated the effect of financial leverage on financial performance of deposit taking Saccos in Kenya. The sample data was extracted from 40 Savings and Credit Co-operative Societies (Saccos) registered by Sacco Society Regulatory Authority (SASRA) extended from the period 2010 to 2012. The results show perfect positive correlation between debt equity ratio with return on equity.

Dey, Adhikari, and Bardhan, (2015) study the firm specific factors affecting the overall financial performance of Thirteen life insurance companies in India for the period 2003-04 to 2012-13. Analysis of the study shows that there is significant negative relationship between leverage and financial performance (ROE). Also, Chinaemerem and Anthony, (2012) examines the impact of capital structure on financial performance of thirty non-financial firms in Nigerian from 2004 - 2010. The result shows that a firm's capital structure surrogated by Debt Ratio, Dr has a significantly negative impact on the firm's financial measures (ROE).

\section{RESEARCH METHODOLOGY}

The study is a qualitative research because it has to do with the collection of data from study firms. The ex-post factor research design is suitable for this study because the study use panel and cross-sectional data. The study adopted census sample techniques because all the 6 population was used for the study. The six (6) multinational firms quoted on the Nigerian stock exchange over a period of 2006 to 2018 was use for the study. The quoted firms are A.G. Leventis (Nigeria) Plc, Chellarams Plc, Johnholt Plc, SCOA Plc, Transactional Corporation Plc, UAC Plc. Multiple regression analysis is applied to examine the impact of firm's debt structure and shareholder returns on investment: The moderating effects of foreign director of Quoted multinational companies in Nigeria. The collected panel data is analysis using descriptive statistics, correlations and multiple linear regression analysis.

In bid to ascertain the impact of firm debt structure and shareholder funds, a Multiple linear model is built.

$$
\begin{aligned}
& \mathrm{SHR}_{\mathrm{it}}=\beta_{0 i t}+\beta_{1} \mathrm{DTA}_{\mathrm{it}}+\beta_{2} \mathrm{DE}_{\mathrm{it}}+\beta_{3} \mathrm{DT} \mathrm{T}_{\mathrm{it}}+\beta_{4} \mathrm{FD}_{\mathrm{it}} \\
& \mathrm{SHR}_{\mathrm{it}}=\beta_{0 \mathrm{it}}+\beta_{1} \mathrm{DTA}_{\mathrm{it}}+\beta_{2} \mathrm{DE}_{\mathrm{it}}+\beta_{3} \mathrm{DT}_{\mathrm{it}}+\beta_{4} \mathrm{FD}_{\mathrm{it}}+\beta_{5} \mathrm{DE} * \mathrm{FD}_{\mathrm{it}}+\beta_{6} \mathrm{DT} * \mathrm{FD}_{\mathrm{it}}+\varepsilon_{\mathrm{it}}+\mathrm{U}_{\mathrm{it}-\ldots+\ldots}
\end{aligned}
$$
Where,

Shareholder returns is proxy by $(\mathrm{ROE})=$ Return on Equity (Abubakar \& Garba, 2019), DT= debt to total asset (Kariyawasam, 2019), DE= Debt to Equity (Fali et al., 2019), DTU= Debt to Turnover, $\mathrm{FD}=$ Foreign Director. $\mathrm{i}=$ number firm observation, $\mathrm{t}=$ measure of time, $\mathrm{E}=$ error term, $U=$ OLS for subject ${ }_{i t}$, and $\beta_{0}=$ Intercept of the model "Constant" 
European Journal of Accounting, Auditing and Finance Research

Vol.8, No. 5, pp.66-84, May 2020

Published by ECRTD-UK

Print ISSN: 2053-4086(Print), Online ISSN: 2053-4094(Online)

\section{RESULTS AND DISCUSSIONS}

Descriptive Result

Table 1. Descriptive results

\begin{tabular}{llllll}
\hline Variables & OBS & Mean & Std. Dev & Min. & Max. \\
\hline SHR & 78 & -0.0225317 & 0.4030031 & -2.52278 & 0.92128 \\
DT & 78 & 0.2983295 & 0.2115198 & 0.0042 & 0.8454 \\
DE & 78 & 1.211699 & 1.663791 & 0.0146 & 10.7362 \\
DTU & 78 & 0.7981795 & 1.483117 & 0.0108 & 9.1162 \\
FD & 78 & 0.3136803 & 0.2241687 & 0 & 0.625 \\
DT/FD & 78 & 0.1011141 & 0.1206912 & 0 & 0.4227 \\
DE/ FD & 78 & 0.4513538 & 0.8098405 & 0 & 4.6012 \\
DTU/FD & 78 & 0.1474321 & 0.2631532 & 0 & 1.9445 \\
\hline
\end{tabular}

\section{Sources: STATA 13 Result Output}

The descriptive statistic results reveal that the mean value of shareholder returns is -0.0225 with minimum value at -2.52 and maximum value at 0.92 . Debt to total asset ratio shows a mean value of 0.2983 with minimum and maximum value of 0.0042 and 08454 respectively. The debt to equity ratio has a mean value of 1.211 with minimum value of 0.0146 and maximum value of 10.7362. Furthermore, debt to turnover of firms has an average mean value of 0.7981 with a minimum and maximum value of 0.0108 and 9.1162 respectively. In the board composition, the average mean of foreign director is 0.313 with minimum number of 0 and maximum of 0.625 . The moderating influence of foreign director in the board composition has reduce the average mean value of debt to total asset from 0.2983 to 0.1011 and debt to equity ratio from 1.211 to 0.45 , while mean value of debt to firm turnover ratio is reduce from 0.7981 to 0.1474 .

\section{Correlation Result}

Table 2: Correlation Matrix

\begin{tabular}{llllllll} 
SHR & DT & DE & DTU & FD & DT/FD & DE/FD & DTUFD \\
\hline
\end{tabular}

SHR 1.0000

DT $\quad-0.1598 \quad 1.0000$

$\mathrm{DE} \quad-0.4981^{*} \quad 0.7675^{*} \quad 1.0000$

DTU $\quad-0.1796 \quad 0.4524 * 0.2610 * 1.0000$

FD $\quad 0.0320 \quad 0.1610 \quad 0.1936 \quad-0.3136 * 1.0000$

DT/FD -0.0556 $0.7451 * 0.6511 *-0.0811 \quad 0.6741^{*} 1.0000$

DE/FD -0.3794* $0.6914 * \quad 0.9288^{*} \quad-0.0270 \quad 0.4362 * 0.8128 * 1.0000$

DTU/FD -0.1354 $0.4074 * \quad 0.3462 * 0.1756 \quad 0.4044 * 0.5608^{*} \quad 0.4439 *$

Sources: STATA 13 Result Output (* indicate significant level @ 5\%) 
From the Table 2 shows the correlation between all pairs of independent variables and the dependent variable in the model. It is observed that there is negative relationship between shareholder returns and debt to total asset, debt to turnover and the moderate role of foreign director on debt to total asset, debt to equity and debt to turnover. The test results on correlation matrix shows that all independent variables and moderating variables have correlation coefficient values $<10$. It concludes that there is no multicollinearity among independent variables and moderating variables in the research model.

\section{Robustness Test for Model One}

Table 3: Robustness test

\begin{tabular}{lll}
\hline Variables & Chi & P-value \\
\hline Mean VIF & 2.10 & \\
Hesttest & 55.75 & 0.0000 \\
Hausman Test & 13.17 & 0.0105 \\
\hline
\end{tabular}

\section{Sources: STATA 13 Result Out}

Multicollinearity is conducted and revealed that VIF value of independent variables is less than the rule of thumb 10 . Hence there is no multicollinearity between independent variables. The fixed effect and random effect model was ran and the Hausman test revealed a p-value of (0.0105) which is significant at 5\% level of significant. Therefore, fixed effect model was accepted. Heteroscedasticity test was conducted to check whether the variability of error terms is constant or not. The result of the test reveals that there is a presence of heteroscedasticity because the hettest chi2 (1) is 55.75 with a p-value of 0.0000 which is statistically significant at $1 \%$ indicating that the data are not homoscedastic but heteroscedastic. This therefore suggests that the original OLS regression will not suit the study, therefore, a panel corrected standard error (PCSE) model was conducted to correct for heteroscedasticity and autocorrelation which is meant to be suitable.

\section{Regression Result without Moderator (Model One)}

The result of the research shows that the value of $\mathrm{R}^{2}$ is 0.4144 . indicating that $41 \%$ of the variance of shareholder return can be explained by independent variables. While the other 59\% explained by other variables not included in this research model. The F-statistics value is 39.91 with a p-value of 0.0000 . This proved the suitability of the model to explain the relationship between the variables that can be used in this study.

\section{Table 4: Summary of PCSS Regression Model}

\begin{tabular}{|c|c|c|c|}
\hline Variables & & Coef. & P-Value \\
\hline DTA & & 1.285372 & 0.000 \\
\hline $\mathrm{DE}$ & & -0.2341372 & 0.000 \\
\hline DTU & & -0.0596344 & 0.015 \\
\hline FD & & 0.0749724 & 0.580 \\
\hline Constant & & -0.0982112 & 0.228 \\
\hline $\mathrm{R}^{2}$ & 0.4144 & & \\
\hline Adjusted $\mathrm{R}^{2}$ & 0.3823 & & \\
\hline F-Statistic & 12.91 & 0.0000 & \\
\hline
\end{tabular}

\section{Sources: STATA 13 Result Out @ 5\% level of significant}




\section{Hypothesis One}

\section{Firm Debt Structure and shareholder Returns}

The result of the model in table 4 revealed that debt to total asset ratio (DT) has a coefficient value of 1.285 with a p-value of 0.000 , this means that debt to total asset (DTA) has a significant and positive impact on shareholder returns. This imply that a $1 \%$ in increase in firm debt to total asset value (DTA) will increase the shareholders returns by $1.2 \%$. Furthermore, debt to equity ratio (DE) has a coefficient value of -0.2341372 with $p$-value at 0.000 , this shows that DE has a negative and significant impact on return on shareholder fund. This implies that a $1 \%$ increase DE will decrease the returns on shareholder funds by $23 \%$. The result suggested that the study firms should reduce its concentration on borrowing and debt.

Debt to firm turnover ratio has a coefficient value of -0.0596344 and $p$-value of 0.015 . This signifies that debt to turnover ratio is negative and significantly impacted on return on shareholder fund. This implies that, $1 \%$ increase in debt to turnover ratio will also decrease or reduce the returns on shareholder fund by $5 \%$. This signifies that turnover of the firm cannot services the debt structure of the firms, thereby reduce the returns on the shareholders fund. The result negates agency theory which argues as the presence of debt or borrowing by firms is supposed to align the interest of the shareholders. Therefore, the null hypothesis was rejected for the three hypotheses tested above which presumed that firm debt structure has no significant impact on return on shareholder funds.

Finally, Foreign directors have a coefficient value of 0.0749724 with a p value of 0.580 . This signifies that foreign directors have a positive and insignificant impact on return on shareholder fund. This indicates that a $1 \%$ increase in foreign director will lead to increase in returns on shareholder fund. Therefore, the null hypothesis was accepted and concluded that FD has no significant impact on return on shareholder fund.

\section{Robustness Test for Model Two}

Table 5:Robustness test for Moderator Model .

\begin{tabular}{lcc}
\hline Variables & Chi & P-value \\
\hline Hesttest & 35.69 & 0.0000 \\
Hausman Test & 13.40 & 0.0630 \\
LM test & 0.00 & 1.0000 \\
\hline
\end{tabular}

\section{Sources: STATA 13 Result Out}

Considering the nature of the domain multinational companies, the study tested for linearity between the role of moderator on firm debt structure and shareholders returns. The fixed effect and random effect model was conducted and the result of Hausman test revealed a chi2 value of 13.40 with a p-value of 0.0630 , which is not significant at $5 \%$ level of significant. Thus, LM test was conducted in order to be guided in deciding which regression model best fit the study between the random effect regression model and the OLS regression model. The result of LM test revealed a chibar 2 of 000 with a p-value of 1.0000 which is not significant, this suggests that OLS regression model best suitable for the study. 
However, Heteroscedasticity test was conducted, and the result reveals the presence of heteroscedasticity because the hettest chi2 (1) is 35.69 with a p-value of 0.0000 which is significant at $1 \%$ indicating that the data are not homoscedastic but heteroscedastic. This therefore suggests that the original OLS regression will not suit the study. This found the suitability of FGLS model for the study for correction of heteroscedasticity and autocorrelation in the study and also the study has a higher time period of thirteen (13) and few numbers of company of six (6).

\section{Regression Result with Moderator}

The result of the research shows that F-statistics value is 69.86 with a p-value of 0.0000 . This proved the suitability of the model to explain the moderating role on the relationship between the independent variables and dependent variable variables.

Table 6: Summary of FGLS Regression Model with Moderator

\begin{tabular}{lccc}
\hline Variables & Coefficient & P>IZI & P-Value \\
\hline DTA & 0.9406936 & 1.51 & 0.132 \\
DE & -0.5526282 & -3.80 & 0.000 \\
DTU & 0.0641887 & 1.24 & 0.215 \\
FD & -0.2885851 & -0.94 & 0.349 \\
DTA/FD & $\mathbf{0 . 4 0 2 3 9 3 2}$ & $\mathbf{0 . 2 8}$ & $\mathbf{0 . 7 7 9}$ \\
DE/FD & $\mathbf{0 . 7 4 0 7 3 0 5}$ & $\mathbf{2 . 2 0}$ & $\mathbf{0 . 0 2 8}$ \\
DTU/FD & $\mathbf{- 0 . 3 8 5 3 4 4 4}$ & $\mathbf{- 2 . 1 3}$ & $\mathbf{0 . 0 3 3}$ \\
Constant & 0.0875336 & 0.70 & 0.484 \\
\hline F-Statistic & $\mathbf{1 2 . 9 1}$ & & $\mathbf{0 . 0 0 0 0}$
\end{tabular}

Sources: STATA 13 Result Out @ 5\% level of significant

\section{Hypothesis Two}

\section{Firm Debt Structure and Shareholders Returns}

The regression results in table 6 reveal that debt to total asset (DTA) has a coefficient value of 0.9406 with a p-value of 0.132 . This indicate that DTA ratio is positive and insignificant effect on shareholders returns, this shows that a $1 \%$ increase in DTA increase the returns on shareholders by $94 \%$. Furthermore, the debt to equity (DE) ratio has coefficient value of 0.5526282 with a p-value of 0.000 . This signified that DE ratio is significant and negatively influencing the return on shareholders' fund. However, when an increase in debt to equity rises by $1 \%$ this will drastically reduce the returns to the shareholders by $55 \%$.

The debt to turnover (DTU) ratio has a coefficient value of 0.0641887 with a p-value of 0.215 . This shows that debt to turnover ratio has a positive and insignificant impact on return on shareholder. This implies that the turnover of the study firm can accommodate the debt structure of the firm without any negative impact on shareholder funds. An increase in the ratio will lead to $6 \%$ increase on the return on shareholder funds.

\section{Foreign Directors as a Moderator to Firm Debt Structure on Shareholders Returns}

Foreign director as a moderator on the relationship between debt to total asset (DTA) ratio and return on shareholder fund has a coefficient value of 0.4023932 with a $p$-value of 0.779 . This shows that DTA ratio has a positive and insignificant effect on the returns to the shareholders. Foreign director as a moderator to the debt to equity ratio (DE) and return on shareholder fund has a coefficient value of 0.7407305 with a p-value of 0.028 . This shows that debt to equity 
ratio has a positive and significant effect on the returns to the shareholders due to the moderating role of foreign of directors in the composition of the study firms. This implies that the foreign director has greater role to play in terms of managing the debt structure of the firms and getting a good return on equity fund, and this due to their foreign expertise and experience.

Finally, Foreign directors as moderator to the debt to turnover ratio (DTU) and shareholder returns has coefficient value of -0.3853444 with a $p$-value of 0.033 . This shows that debt to turnover ratio has a positive and significant effect on the returns to the shareholders and this due to the moderating role of foreign of directors in the composition of the study firms. This means that $1 \%$ increase in the debt to firm turnover will lead to a decrease in returns on shareholders fund.

\section{CONCLUSION AND RECOMMENDATIONS}

This study examines the moderating role of foreign director on the relationship between firm debt structure and returns on shareholder of listed multinationals firms in Nigeria during the period 2006- 2018. DTA, DE and DTU were used as proxies for firm debt structure, while ROE was used as proxy for the shareholder returns. Data was sourced from the annual reports of the companies selected for the 13-year period. Descriptive statistics and panel data techniques were used as methods of analyses. F-test and Hausman test were conducted to select the best model among the panel estimators, while Robust Heteroscedasticity- and Autocorrelation Consistent (HAC) standard errors were applied to deal with Autocorrelation and Heteroscedasticity problems. Correlation matrix and VIF were used to detect presence or otherwise of multicollinearity and the results affirmed that there is no multicollinearity.

Results from the chosen regression PCSE for model one revealed that debt to total asset has a positive and significant effect on shareholder returns while debt to equity and debt to turnover have a significant and negative effect on shareholder returns. Furthermore, FGLS regression revealed in model two that the moderating role of foreign directors show that the debt to total asset has a positive and insignificant effect on shareholders returns, while debt to equity ratio has a positive and significant effect on returns on shareholders, and also, shows that debt to turnover reveal a negative and significant effect on shareholders returns.

Based on the findings of the study the following conclusions are drawn.

The study concludes that firm debt structure influences the shareholder returns of six (6) multinationals companies confirmed by the highly significant F-value. The study also concluded that the combination of total debts in the debt structure of firms in Conglomerate Sector will not improve shareholder returns measured by the ROE. However, shareholder funds especially debt to total asset ratio will enhance returns. It is also concluded that the current debt-equity mix of the firms in the Conglomerates Sector is favourable to the company if the foreign director are allowed to participate fully in the governance of the companies. Foreign director can play an important role in using total-debt equity ratio to improve the shareholder returns as measured by ROE. Though firm turnover has been found not to mitigate in serving the debt structure of the companies, because it has decline and reduce shareholders return despite the intervention of foreign expertise. 
i. The study concludes that, the observed negative significant relationship between debt to equity ratio and shareholder value of listed multinationals firms in Nigeria with and without the monitoring effect of foreign director was since high debt and lack of proper management of debt by the firm. More so, inexperience personnel who will be eligible to come up with useful strategies to be implemented that will serve as guide against poor debt management. However, it is believed that with good strategies of debt management both existing and prospective stakeholder's interest will be covered.

Following the major findings and conclusions, the study recommends that firms in the Conglomerates Sector should adopt a debt-equity mix comprising if the foreign director will be allowed to participate in mix debt structure of company because it has been found to improve the returns to shareholders with about 74\%. Firms in the Conglomerates Sector of the Nigeria Stock Exchange should increase equity to a level that will enable them to achieve a stable and constant debt-equity mix. Equity should be increased through bonus issue, increase in retained earnings and right issue. In addition, the Conglomerates Sector should strategize to improve their sales level or turnover and also reduce unnecessary operational cost in order to enable the companies services the debt structure appropriately because it has proven that the firm debt to turnover is drastically reducing the shareholders returns.

Finally, this study is only limited to firms in the Conglomerate Sector of the Nigeria Stock Exchange. Firms in other sectors such as Agriculture, Industrial Goods, Construction/Real Estates, Consumer Goods, Financial Services, Health Care, Information \& Communication Technology (ICT), Natural Resources, Oil and Gas, and Services are not considered here. Therefore, caution should be exercised when generalizing the findings of this study to other sectors. Additionally, short term debt ratio and long term debt are not consider separately in the study as a measure of debt structure due to collinearity problem; and other market performance indicators such as earnings per share (EPS), price earnings ratio (P/E) among others are not utilized in this study. Therefore, future researchers in this area should consider incorporating these variables in their study

\section{Reference}

Abbasi, E., \& Delghandi, M. (2016). Impact of firm specific factors on capital structure based on trade off theory and pecking order theory - An empirical study of the Tehran ' $\mathrm{s}$ stock market companies. Arabian Journal of Business and Review, 6(2), 2-5. https://doi.org/10.4172/2223-5833.1000195

Abubakar, A. (2017). Financial leverage and financial performance of quoted services firms in Nigeria. KASU Journal of Management Sciences, 8(2), 89-108.

Abubakar, A., \& Garba, A. (2019). Financial leverage and financial performance of quoted services firms in Nigeria. Nigerian Journal of Management Technology \& Development, 4(2), 8-13.

Afza, Talat., Amer, H. (2011). Determinants of capital structure across selected manufacturing sectors of Patistan. International Journal of Humanities and Social Science, 1(12), 254262.

Ahmad, N., \& Mohsin. (2016). Impact of capital structure on firm 's financial performance : Cement Industry of Pakistan. European Journal of Business and Management, 8(4), 115-119. 
European Journal of Accounting, Auditing and Finance Research

Vol.8, No. 5, pp.66-84, May 2020

Published by ECRTD-UK

Print ISSN: 2053-4086(Print), Online ISSN: 2053-4094(Online)

Afolabi, A., Olabisi, J., Kajola, S. O., \& Asaolu, T. O. (2019). Does leverage affect the financial performance of Nigerian firms? Journal of Economics and Management, 37(3), 5-22. https://doi.org/10.22367/jem.2019.37.01

Chinaemerem, O. C., \& Anthony, and O. (2012). Impact Of Capital Structure On The Financial Performance Of Nigerian Firms. Arabian Journal of Business and Management Review, 1(12), 43-61.

Bhutta, N. T., \& Hasan, A. (2013). Impact of firm specific factors on profitability of firms in

food sector. Open Journal of Accounting, 2, 19-25

Dey, N. B., Adhikari, K., \& Bardhan, M. R. (2015). Factor Determining Financing Performance of Life insurance Companies of India-an Empirical Study. EPRA International Journal of Economic and Business Review, 2(8), 42-48.

Elshaday, T., Kenenisa, D., \& Mohammed, S. (2018). Determinant of financial performance of commercial banks in Ethiopia: Special emphasis on private commercial banks. African Journal of Business Management, 12(1), 1-10. https://doi.org/10.5897/ajbm2017.8470

Fali, I. M., Ibenre, N. A., \& Mustapha, L. O. (2019). Leverage and Financial Performance of Islamic Banking in Nigeria. The International Journal of Business \& Management, 7(7), 198-206. https://doi.org/10.24940/theijbm/2019/v7/i7/bm1907-036

Gweyi, M. O., \& Karanja, J. (2014). Effect of Financial Leverage on Financial Performance of Deposit Taking Savings and Credit Co-operative in Kenya. International Journal of Academic Research in Accounting, Finance and Management Sciences, 4(2), 180-188. https://doi.org/10.6007/IJARAFMS/v4-i2/838

Hussain, Z., Rao, H., Akram, B., \& Fayyaz, M. (2015). Effect of Financial Leverage on Performance of the Firms : Empirical Evidence from Pakistan. SPOUDAI Journal of Economics and Business, 65(1), 87-95.

Innocent, C., Ikechukwu, C., \& Nnagbogu, E. K. (2014). The Effect of Financial Leverage on Financial Performance : Evidence of Quoted Pharmaceutical Companies in Nigeria . IOSR Journal of Economics and Finance, 5(3), 17-25.

Jain, B. A., Jayaraman, N., \& Kini, O. (2007). The path-to-profitability of Internet IPO firms «. https://doi.org/10.1016/j.jbusvent.2007.02.004

Kariyawasam, A. H. N. (2019). Analysing the Impact of Financial Ratios on a Company's Financial Performance. International Journal of Management Excellence, 13(2), 18981903.

Kouse, R., Bano, T., Azeem, M., \& Hassan, M. (2012). Inter-Relationship between Profitability , Growth and Size: A Case of Non-Financial Companies from. Pak.J. Commer. Soc. Sci, 6(2), 405-419.

Lasisi, I. O., Dikki, C. A., \& Okpanachi, J. (2017). Empirical determinant of firm's profitability: evidence from listed agricultural companies in Nigeria. Sahel Analyst: Journal of Management Sciences, University of Maiduguri, Nigeria, 15(8).

Mule, R. K., \& Hons, B. E. (2015). financial leverage and performance of listed firms in a frontier market : panel evidence from Kenya. European Scientific Journal, 11(7), 534550.

Musah, M., \& Kong, Y. (2019). Leverage and financial performance: The correlational approach. International Journal for Innovative Research in Multidisciplinary Field, $5(4), 1-8$.

Ongore, V. O. (2013). Determinants of Financial Performance of Commercial Banks in Kenya. International Journal of Economics and Financial Issues, 3(1), 237-252. 
Print ISSN: 2053-4086(Print), Online ISSN: 2053-4094(Online)

OlumideA. O., Muhammad T., \&Terzungwe N. (2016). Firm structural characteristics and financial reporting quality of listed deposit money banks in Nigeria. International Business Research, 9(1)

Ongore, V. O (2013). Determinants of Financial Performance of Commercial Banks in Kenya. International Journal of Economics and Financial Issues, 3(1), 237-252

Okwoli, A.A., kpelai, S.T. (2006). Introduction to Managerial Finance. Tomma Press Ltd. page 170.

Osuji, C. C \& Odita, A. (2012). Impact of capital structure on the financial performance of Nigerian firms, Arabian Journal of Business and Management Review. 1(12).

Raithatha, M., \& Komera, S. (2016). Executive compensation and firm performance : Evidence from Indian firms. IIMB Management Review, 28(3), 160-169. https://doi.org/10.1016/j.iimb.2016.07.002

Swain, D. R. K., \& Das, C. P. (2017). Impact of Capital Structure on Financial Performance and its Determinants. International Journal of Informative \& Futuristic Research, 4(11), 8404-8413.

Sathyamoorthi, C. R., Mapharing, M., Mphoeng, M., \& Dzimiri, M. (2019). Impact of Financial Risk Management Practices on Financial Performance: Evidence from Commercial Banks in Botswana. Applied Finance and Accounting, 6(1), 25. https://doi.org/10.11114/afa.v6i1.4650 
European Journal of Accounting, Auditing and Finance Research

Vol.8, No. 5, pp.66-84, May 2020

Published by ECRTD-UK

Print ISSN: 2053-4086(Print), Online ISSN: 2053-4094(Online)

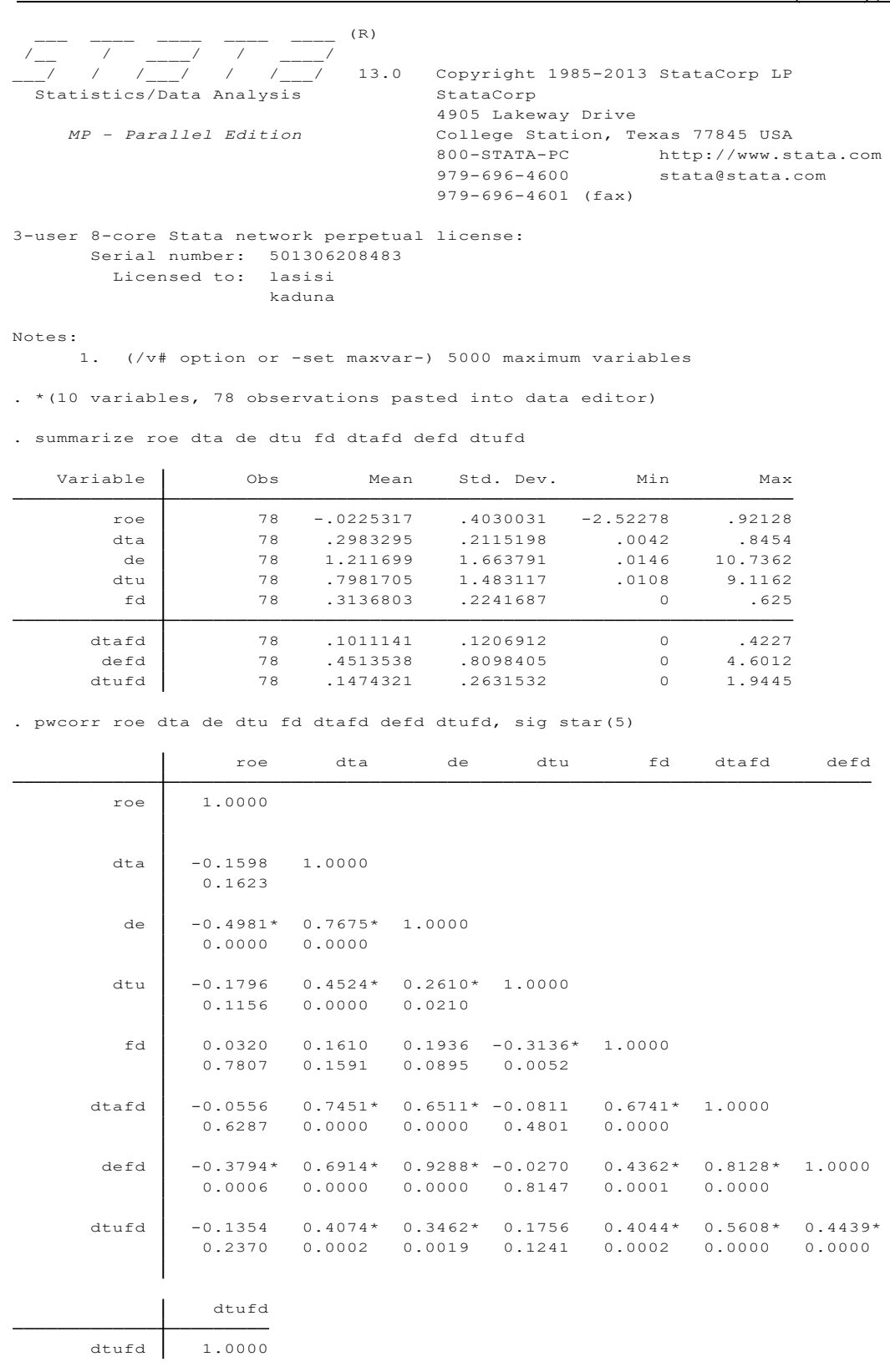


European Journal of Accounting, Auditing and Finance Research

Vol.8, No. 5, pp.66-84, May 2020

Published by ECRTD-UK

Print ISSN: 2053-4086(Print), Online ISSN: 2053-4094(Online)

- regress roe dta de dtu fd

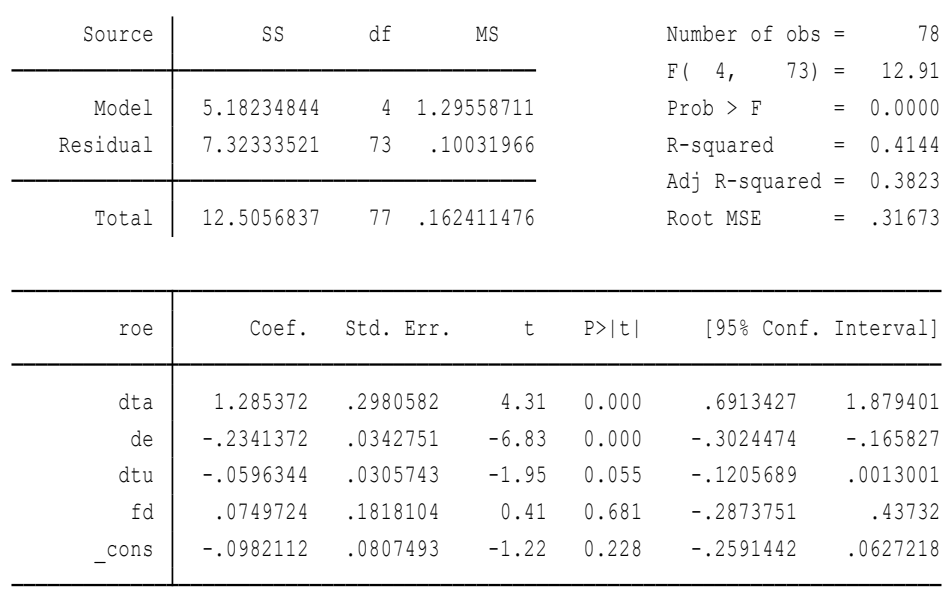

. estat vif

\begin{tabular}{r|rr} 
Variable & VIF & $1 /$ VIF \\
\hline dta & 3.05 & 0.327787 \\
de & 2.50 & 0.400627 \\
dtu & 1.58 & 0.633623 \\
fd & 1.27 & 0.784347 \\
\hline Mean VIF & 2.10 & \\
. estat hettest & &
\end{tabular}

Breusch-Pagan / Cook-Weisberg test for heteroskedasticity

Ho: Constant variance

Variables: fitted values of roe

$\operatorname{chi2}(1)=55.75$

Prob $>$ chi2 $=0.0000$ 
European Journal of Accounting, Auditing and Finance Research

Vol.8, No. 5, pp.66-84, May 2020

Published by ECRTD-UK

Print ISSN: 2053-4086(Print), Online ISSN: 2053-4094(Online)

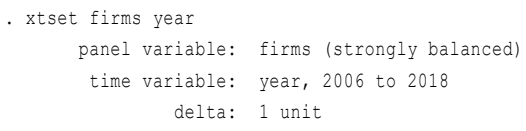

\begin{tabular}{r|rlrrrr}
\hline roe & Coef. & Std. Err. & $t$ & $\mathrm{P}>|\mathrm{t}|$ & [95\% Conf. Interval] \\
\hline dta & 1.503249 & .3735744 & 4.02 & 0.000 & .7577932 & 2.248705 \\
de & -.2147738 & .0337142 & -6.37 & 0.000 & -.2820495 & -.147498 \\
dtu & -.096684 & .0355022 & -2.72 & 0.008 & -.1675276 & -.0258404 \\
$\mathrm{fd}$ & 1.491013 & .4390504 & 3.40 & 0.001 & .6149014 & 2.367124 \\
-cons $^{\text {con }}$ & -.6012851 & .1731597 & -3.47 & 0.001 & -.94682 & -.2557503 \\
\hline sigma_u & .40914351 & & & & & \\
sigma_e & .29987697 & & & & \\
rho & .65053402 & (fraction of variance due to u_i) & \\
\end{tabular}

F test that all u_i=0: $\quad F(5,68)=2.69 \quad$ Prob $>F=0.0282$

. estimates store fixed 
European Journal of Accounting, Auditing and Finance Research

Vol.8, No. 5, pp.66-84, May 2020

Published by ECRTD-UK

Print ISSN: 2053-4086(Print), Online ISSN: 2053-4094(Online)

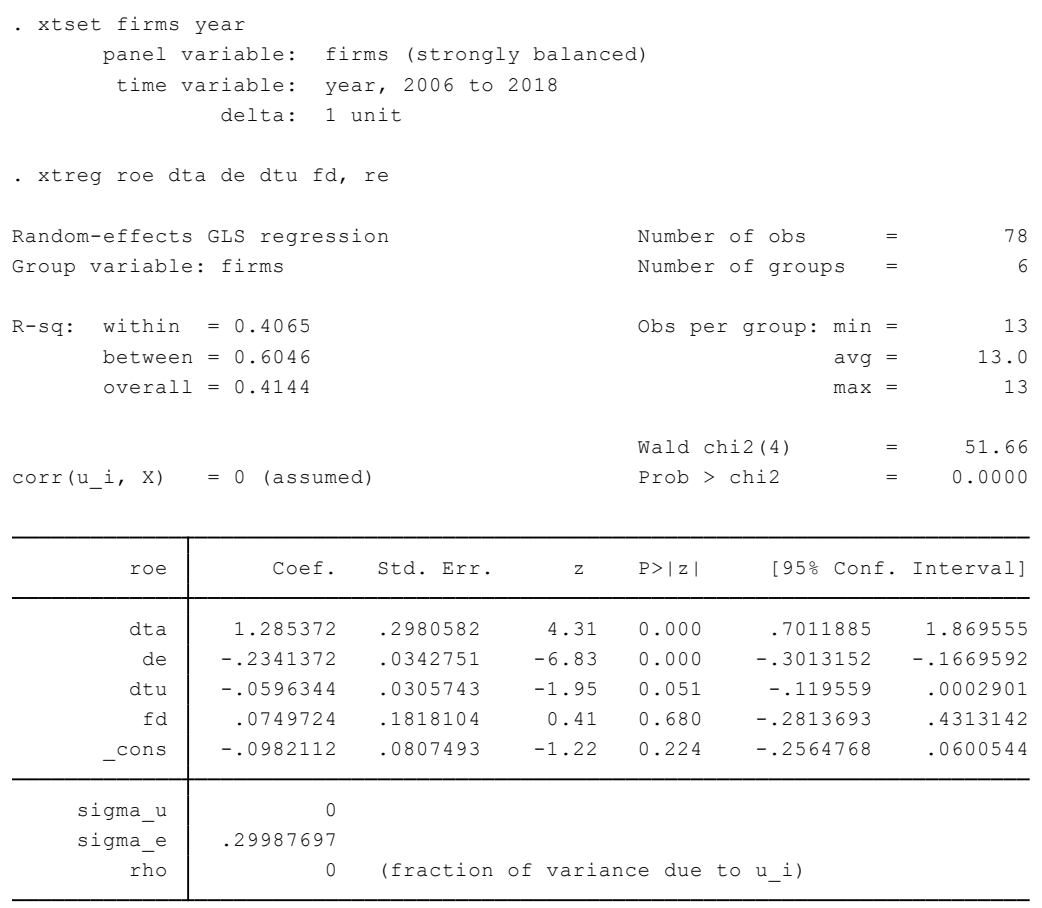

- estimates store random

. hausman fixed random

\begin{tabular}{|c|c|c|c|c|}
\hline & \multicolumn{2}{|c|}{ - Coefficients -} & \multirow{3}{*}{$\begin{array}{c}(b-B) \\
\text { Difference }\end{array}$} & \multirow{3}{*}{$\begin{array}{c}\operatorname{sqrt}\left(\operatorname{diag}_{\left.\left(V_{-} b-V_{-} B\right)\right)}\right. \\
\text { S.E. }\end{array}$} \\
\hline & (b) & (B) & & \\
\hline & fixed & random & & \\
\hline dta & 1.503249 & 1.285372 & .2178775 & .2252092 \\
\hline de & -.2147738 & -.2341372 & .0193634 & . \\
\hline dtu & -.096684 & -.0596344 & -.0370496 & .018045 \\
\hline $\mathrm{fd}$ & 1.491013 & .0749724 & 1.41604 & .3996376 \\
\hline
\end{tabular}

$B=$ inconsistent under $\mathrm{Ha}$, efficient under $\mathrm{Ho}$; obtained from xtreg

Test: Ho: difference in coefficients not systematic

$$
\begin{aligned}
& \operatorname{chi} 2(4)=(b-B) \cdot\left[\left(V_{-} b-V_{-} B\right) \wedge(-1)\right](b-B) \\
& \begin{aligned}
& =13.17 \\
\text { Prob }>\text { chi2 } & =0.0105
\end{aligned} \\
& \text { ( } V_{-} b-V_{-} B \text { is not positive definite) }
\end{aligned}
$$

\begin{tabular}{|c|c|c|c|c|c|c|c|}
\hline Group variabl & firms & & & Number & obs & & 78 \\
\hline Time variable & year & & & Number & group & ps & 6 \\
\hline Panels: & correlated & d (balanced & & Obs pe & group: & $\min$ & 13 \\
\hline Autocorrelati & no autocos & rrelation & & & & avg & 13 \\
\hline & & & & & & $\max$ & \\
\hline Estimated cov & iances $=$ & 21 & & R-squa & & & 0.4144 \\
\hline Estimated aut & orrelations = & $=$ & & wald c & $2(4)$ & & 39.91 \\
\hline Estimated coe & icients $=$ & $=$ & & Prob > & 112 & & 0.0000 \\
\hline & & nel-correct & & & & & \\
\hline roe & Coef. & Std. Err. & $\mathrm{z}$ & $P>|z|$ & {$[95 \%$} & Conf & - Interval] \\
\hline dta & 1.285372 & .353228 & 3.64 & 0.000 & .5930 & 0576 & 1.977686 \\
\hline de & -.2341372 & .0425132 & -5.51 & 0.000 & -.3174 & 4616 & -.1508128 \\
\hline dtu & -.0596344 & .0244995 & -2.43 & 0.015 & -.1076 & 6526 & -.0116163 \\
\hline & .0749724 & .135367 & 0.55 & 0.580 & -.190 & 0342 & .3402869 \\
\hline _cons & -.0982112 & .0640406 & -1.53 & 0.125 & -.2237 & 7284 & .027306 \\
\hline
\end{tabular}

- xtpcse roe dta de dtu fd

Linear regression, correlated panels corrected standard errors (PCSES) 
European Journal of Accounting, Auditing and Finance Research

Vol.8, No. 5, pp.66-84, May 2020

Published by ECRTD-UK

Print ISSN: 2053-4086(Print), Online ISSN: 2053-4094(Online)

- xtreg roe dta de dtu fd dtafd defd dtufd, fe

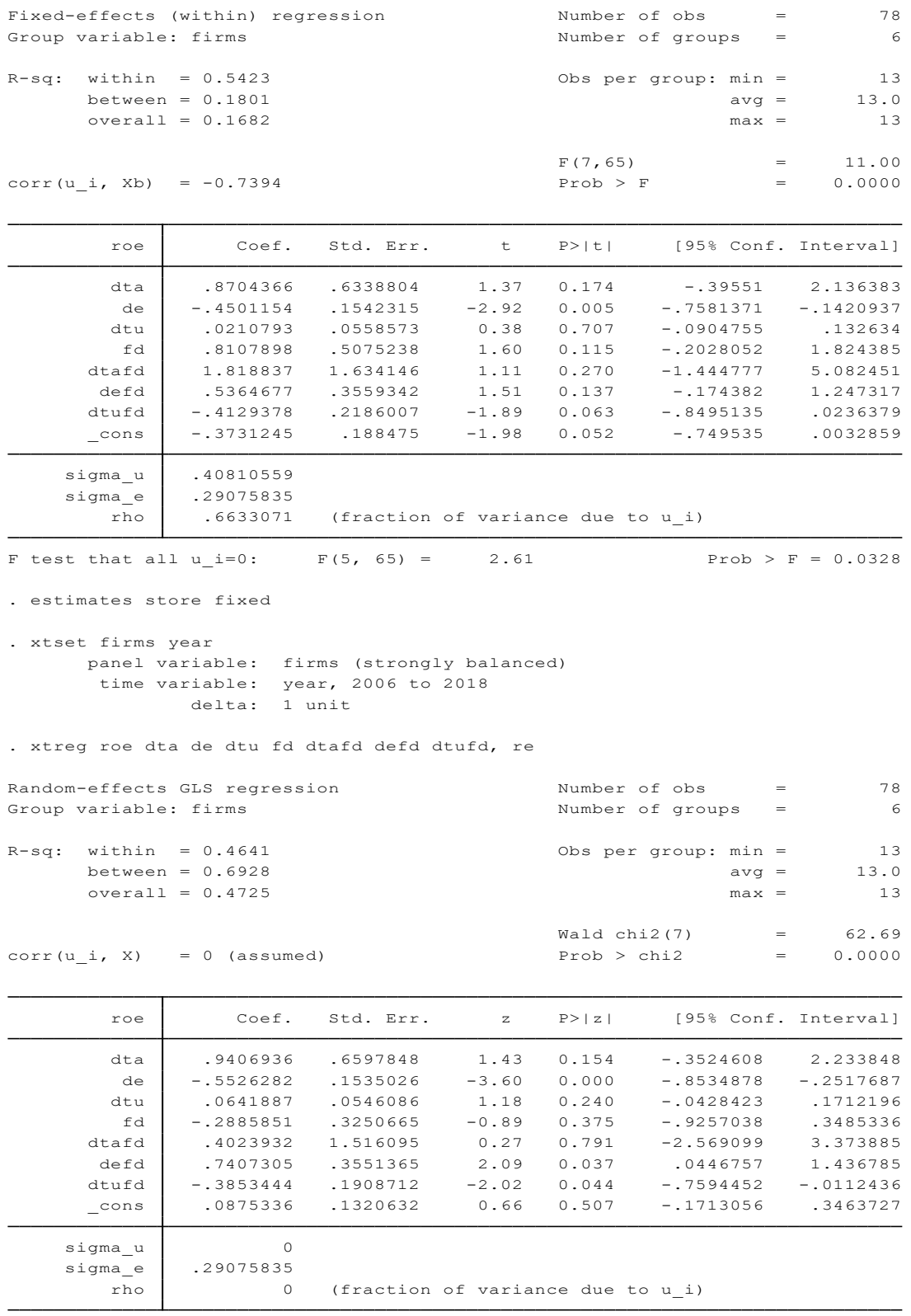

- estimates store random

- hausman fixed random

\begin{tabular}{|c|c|c|c|c|}
\hline & $\begin{array}{c}\text { (b) } \\
\text { fixed }\end{array}$ & $\begin{array}{l}\text { ients } \\
\text { (B) } \\
\text { random }\end{array}$ & $\begin{array}{c}(\mathrm{b}-\mathrm{B}) \\
\text { Difference }\end{array}$ & $\begin{array}{c}\operatorname{sqrt}\left(\text { diag }_{(\mathrm{a}} \mathrm{V}_{\left.\mathrm{b}-\mathrm{V}_{-} \mathrm{B}\right)}\right) \\
\text { S.E. }\end{array}$ \\
\hline dta & .8704366 & .9406936 & -.070257 & - \\
\hline de & -.4501154 & -.5526282 & .1025129 & .0149774 \\
\hline$d t u$ & .0210793 & .0641887 & -.0431094 & .0117447 \\
\hline$f d$ & .8107898 & -.2885851 & 1.099375 & .3897591 \\
\hline dtafd & 1.818837 & .4023932 & 1.416444 & .6098251 \\
\hline defd & .5364677 & .7407305 & -.2042628 & .0238164 \\
\hline dtufd & -.4129378 & -.3853444 & -.0275934 & .1065571 \\
\hline
\end{tabular}

$\mathrm{b}=$ consistent under $\mathrm{Ho}$ and $\mathrm{Ha}$; obtained from xtreg

Test: Ho: difference in coefficients not systematic

\begin{tabular}{|c|c|}
\hline chi2 (7) & $=(b-B) \cdot\left[\left(V_{-} b-V_{-} B\right) \wedge(-1)\right](b-B)$ \\
\hline & $=13 . \overline{4} 0$ \\
\hline & 0.0630 \\
\hline
\end{tabular}


- xttesto

Breusch and Pagan Lagrangian multiplier test for random effects

\begin{tabular}{|c|c|c|}
\hline Estimated results & Var & $\operatorname{sd}=\operatorname{sqrt}(\operatorname{Var})$ \\
\hline roe & .1624115 & .4030031 \\
\hline e & .0845404 & .2907583 \\
\hline u & 0 & 0 \\
\hline
\end{tabular}

Test: $\operatorname{Var}(u)=0$

$$
\begin{array}{rr}
\text { Chibar2 }(01) & =0.00 \\
\text { Prob }>\text { chibar2 } & =1.0000
\end{array}
$$

\begin{tabular}{|c|c|c|c|c|c|c|c|}
\hline Source & SS & $d f$ & \multicolumn{2}{|c|}{ MS } & & $\begin{array}{l}\text { Number of obs } \\
\mathrm{F}(7, \quad 70)\end{array}$ & 78 \\
\hline Model & 5.90848816 & 7 & .84 & 69737 & & Prob > F & 0.0000 \\
\hline Residual & 6.59719549 & 70 & .0 & 24565 & & R-squared & 0.4725 \\
\hline Totol & 125056837 & 77 & $167^{3}$ & 11.476 & & Bent MCF & 30609 \\
\hline roe & Coef. & std. & Err. & t & $P>|t|$ & [95\% Conf. & Interval] \\
\hline dta & .9406936 & .6597 & 7848 & 1.43 & 0.158 & -.3752057 & 2.256593 \\
\hline de & -.5526282 & .1535 & 5026 & -3.60 & 0.001 & -.8587795 & -.246477 \\
\hline$d t u$ & .0641887 & $.0546 \mathrm{rght}$ & 6086 & 1.18 & 0.244 & -.0447248 & .1731021 \\
\hline $\mathrm{fd}$ & -.2885851 & .3250 & 0665 & -0.89 & 0.378 & -.9369099 & .3597396 \\
\hline$d$ tafd & .4023932 & 1.516 & 5095 & 0.27 & 0.791 & -2.621363 & 3.42615 \\
\hline defd & .7407305 & .3551 & 1365 & 2.09 & 0.041 & .032433 & 1.449028 \\
\hline dtufd & -.3853444 & .1908 & 3712 & -2.02 & 0.047 & -.7660251 & -.0046637 \\
\hline cons & .0875336 & .1320 & 632 & 0.66 & 0.510 & -.1758582 & .3509253 \\
\hline
\end{tabular}

- regress roe dta de dtu fd dtafd defd dtufd

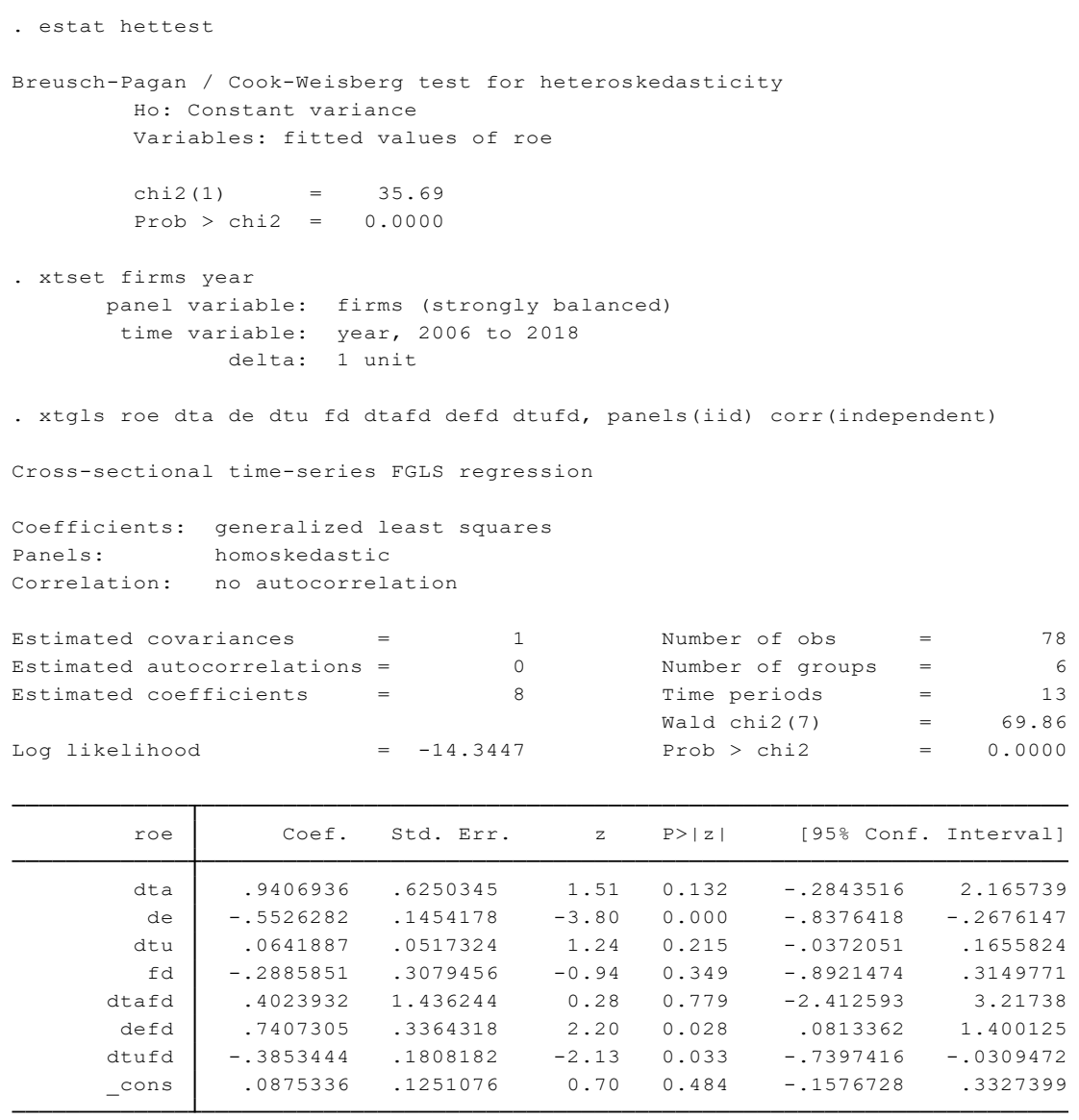

